\title{
IMPACT OF GUANXI ON MANAGERIAL SATISFACTION AND COMMITMENT IN CHINA
}

\author{
Jeffrey (Jun) Chen ${ }^{1 *}$ and Patrick F. O'Leary ${ }^{2}$ \\ ${ }^{1}$ College of Business, North Dakota State University, Fargo, ND 58108, USA \\ ${ }^{2}$ Department of Managerial Studies, St. Ambrose University, Davenport, IA 52803, USA \\ *Corresponding author: jun.chen1@ndsu.edu
}

Published online: 29 June 2018

To cite this article: Chen, J. and O'Leary, P.F. (2018). Impact of guanxi on managerial satisfaction and commitment in China. Asian Academy of Management Journal, 23(1), 171-198. https://doi.org/10.21315/aamj2018.23.1.8

To link to this article: https://doi.org/10.21315/aamj2018.23.1.8

\begin{abstract}
This study assesses the role of guanxi (relationship) in organisational commitment and job satisfaction among mid-level managers in China today. Based on a large survey sample, we quantitatively identify three components of guanxi by adopting the principal component analysis (PCA), and then apply the multivariate regressions to examine the impact of guanxi. Our research unveils how guanxi dimensions, a type of social connection with features of Chinese culture, exert unique and practical impacts on the work environment. Consistent with the literature, organisational guanxi is confirmed to enhance job satisfaction and affective commitment, while personal guanxi is found to undermine job satisfaction and affective commitment. On the other hand, organisational guanxi tends to reduce continuance or normative commitment while personal guanxi improves both. These findings contribute to the literature with evidence highlighting the importance of guanxi in human resources management and also shed new light to the heterogeneity of such influence across geographical locations, demographic variation, and forms of organisation. Overall, this research suggests that the ability to navigate different dimensions of guanxi is a necessary skill for the managers in Chinese business.
\end{abstract}

Keywords: guanxi, job satisfaction, organisational commitment, managerial practice, business culture

(C) Asian Academy of Management and Penerbit Universiti Sains Malaysia, 2018. This work is licensed under the terms of the Creative Commons Attribution (CC BY) (http://creativecommons. org/licenses/by/4.0/). 


\section{INTRODUCTION}

The lifeblood of the Chinese company is personal connections. Central to those connections are the Confucian values of order, hierarchy, and deference to authority. While Confucianism describes a social system and draws primarily on custom rather than religion, it leads to management practices that are more instinctive, less openly discussed, and more natural than those in the West (Warner, 2010). In this Confucian sphere, personal relationships are nurtured and sustained through guanxi, a term that refers to reciprocal trust, favours, influence, and obligations (Tsui, Farh, \& Xin, 2000) and manifests itself through interpersonal connections. Li (2007a, 2007b) suggests that guanxi is deeply rooted in the local culture and therefore plays a role of personalised social capital as a dominant norm in China. For the purposes of this paper, guanxi refers to the general relationship between supervisor and subordinate. In contrast with clansmen guanxi based on familiar ties and community ties, workplace guanxi can be seen as a good relationship between two parties not based on the historical origin of that relationship (Cheung, Wu, Chan, \& Wong, 2009; Bedford, 2011).

By conducting a survey on a large sample of subjects, we provide one of first empirical evidences to explore the significant influence of guanxi on Chinese managerial practices. While guanxi and the Western concept of networking have much in common, there are significant cultural differences. Lo (2012) notes that guanxi places a stronger emphasis on reciprocity, has a longer-term time orientation, and possesses a culturally specific etiquette for building relationships. Whereas a distinctive industrial capitalism has taken shape in China today, Pun, Chin, and Lau (2000) point out the guanxi culture remains prevailing and strongly impacts centralised authority, hierarchical structure, managerial philosophy, employees' commitment and job satisfaction in Chinese business. Allott, Gibb, and Akoorie (2017) argue that guanxi can improve cooperative trust, reduce uncertainty of investment, and hence contribute to the development of benevolence. By contrast, the extant literature also highlights the controversial consequence of using guanxi in Chinese business. For example, the abuse of guanxi is associated with the corruption, violation of organisational rules, and erosion of trust in the management (Murray \& Fu, 2016). This research recognises these profiles of guanxi and also sheds light on how different dimensions of guanxi, a type of social connection with features of Chinese culture, exert unique and practical impacts on the work environment. 


\section{LITERATURE REVIEW AND HYPOTHESES DEVELOPMENT}

The traditional Chinese business centres on people and focuses on the relationship between people, such as humanity or benevolence, righteousness, propriety, wisdom, and trustworthiness (Watt, 1999). There is no surprise when the farming economy heavily relies on the network of bartering, guanxi becomes a well-known "secret" of doing successful business as it connects the individuals and motivates both parties to derive benefits from each other and to maintain and nourish such relationship over time. Gannon and Pillai (2013, p. 456) observe that penetrating the layers of guanxi is like "peeling an onion: first come connections between people with ancestors; then between people from the same village; then between members of the family; and finally between the family and close associates who can be trusted, such as the competent executives who are not family members but who actually run the factories." While differing conceptualisations reflects the differences in the nature, motivation and underlying values of the exchange participants, there is a general agreement that guanxi has a status, respect, and credibility component, is based on mutual trust and respect for social norms, has a long-term orientation, and is sustained on favours, consideration, and emotional commitment.

According to Chen, Chen, and Huang (2013, p. 171) workplace guanxi "tends to be a mixture of family and non-family, personal and impersonal, and expressive and instrumental characteristics." Bedford (2011) asserts that working guanxi is a process between individuals who may or may not have a common base from the past but who are building a private channel through which they can exchange favours, information, and affection to get things done at work. However, Fan (2002) cautions that the existence of a guanxi base is not in itself sufficient to ensure there is active guanxi between two parties. It has to be actively nurtured.

The conceptual framework for this study is based on theories of social exchange, leader-member exchange, and Chinese trust principles of reciprocity and face. Thus, the term is conceptualised as a dynamic concept regulated by the interaction of the universal (macro), interpersonal (social), and intrapersonal (cognitive) systems. Particularly, social exchange theory is generally attributed to George Homans who defined it as "the exchange of activity, tangible or intangible, and more or less rewarding or costly, between at least two persons" (Homans, 1961, p. 13). Peter Blau (1977) adds a utilitarian dimension noting that every individual in the exchange is trying to maximise their wins by keeping costs below rewards. This parallels with Fan (2002) who noted that since the development of workplace guanxi requires the expenditure of valuable resources such as time, energy, and sometime money, participants are very aware of real or anticipated returns. 
Leader-member exchange theory stresses the importance of establishing individual links between a leader and each subordinate. It shifted leadership from being viewed as unidirectional, leader influencing a group of followers, to bidirectional whereby the leader establishes variable relationships with each of their subordinates. The theory has been used to create a leadership-making process of three phases in which leaders and subordinates engage in increasingly reciprocal investments in one another that contribute to relational maturity (Graen \& Uhl-Bien, 1991). These stages evolve from the stranger phase based on job description, to the acquaintance phase of increasing interactions which carry the participants beyond minimal contractual obligation, through to the maturity phase which reflects a long-term, reciprocal investment that manifests itself in complimentary behaviours and emotional connection. Thus, while participants in organisational guanxi may not have a common history to draw upon, they can build on the anticipation of future exchanges based on similar intentions (Chen $\&$ Chen, 2004).

In the West, most definitions of trust contain a reliance dimension as well as an element of personal vulnerability (Blois, 1999). In the business context, Morgan and Hunt (1994) define the concept in terms of a partner's reliability, integrity, and competence. Trust in China is a more complex and contextual construct that is associated with many other Chinese characteristics. Fang (1999) notes its association with politics, philosophy, family, and corporate style. Han, Peng, and Zhu (2012) find that workplace guanxi between supervisor and subordinate was a significant predictor of trust between them. Wong, Ngo, and Wong (2003) conceptualise this type of guanxi as stemming from social connections based on mutual interest and benefits whether current or anticipated.

The dispositional model of job satisfaction (Staw \& Cohen-Charash, 2005) suggests that an individual's disposition influences their interactions and relationships, as well as their processing of information regarding their work. As guanxi is based on the principle of mutual trust and emotional engagement, it is reasonable to suggest that its workplace manifestation influences an individual's emotional orientation towards their job. Cheung et al. (2009) find that subordinates having good guanxi with supervisors and co-workers feel valued, and hold a positive attitude towards their jobs.

Bedford (2011) describes a social process model of workplace guanxi whereby individuals are building relationships over time that include both affective and instrumental components. In a high power distance country such as China, the desire to maintain face in front of a guanxi partner often translates into improved trust and satisfaction and discourages opportunistic behaviour. 
Work engagement is a Western concept that refers to the harnessing of organisation member's selves to their work roles whereby they employ and express themselves physically, emotionally, and mentally during work (Kahn, 1990). The work engagement concept was developed in combination with the job demands-resources model that categorises all aspects of the work environment into job demands or job resources that either positively or negatively affect work engagement and satisfaction (Bakker \& Demerouti, 2007). Wei, Liu, Chen, and $\mathrm{Wu}$ (2010) find that employees with good supervisor-subordinate guanxi receive more rewards such as bonuses, as well as development and promotional opportunities. In summary, organisational guanxi appears to have both a direct and an indirect effect on job satisfaction.

On the other hand, employees who have good personal guanxi with supervisors tend to be treated as in-group members with special privileges and favours. However, these outcomes are usually not regarded as fair arrangements even within the group and the political awareness raised can result in lower overall job satisfaction as every employee may worry about being a victim of political intrigue (Gandz \& Murray, 1980). Zhang, Long, Wu, and Huang (2015) find common human resource management practice, such as staffing, promotion, and performance appraisal is affected by interpersonal connections rather than rules and regulations. When guanxi undermines employees' trust in management, it can weaken the reward of employees' compensation for performance on their creativity. Therefore, our hypothesis one is proposed as follows:

H1: There is a positive relationship between organisational guanxi and employee job satisfaction, and a negative relationship between personal guanxi and employee job satisfaction.

Another stream of research connects job satisfaction with commitment (Mowday, Porter, \& Steer, 1982; Meyer \& Allen, 1997; Schwartz, 1999). Organisational commitment is defined as "the relative strength of an individual's identification with and involvement in a particular organization" (Mowday et al., 1982, p. 27). It is a multidimensional construct (Meyer \& Allen, 1997) comprised of three components: affective (emotional attachment, loyalty, identification, and involvement with an organisation), continuance (turnover intentions), and normative commitment (feelings of obligation to an organisation). Research suggests that central components of commitment are shared values, goals congruence, and affinity with organisational members. Shared values are the "extent to which partners have beliefs in common about what behaviours, goals, and policies are important or ... appropriate" (Morgan \& Hunt, 1994, p. 27) while 
work values are generally defined as "the goals or rewards people seek through their work, and they are expressions of more general human values in the context of the work setting" (Schwartz, 1999, p. 43).

In a rapidly changing and diverse organisational environment, there is significant variation in human resource practices with concomitant variation in levels of employee commitment. For example, Gamble and Huang (2008) find that feeling proud of one's employer, good relationships between management and employees, and job security were good predictors of Chinese workers' willingness to stay. Ramasamy, Goh, and Yeung (2006) suggest that good guanxi in the workplace increases the level of trust and facilitates knowledge transfer. Takeuchi, Wakabayashi, and Chen (2003) find that high levels of organisational commitment are attributed to the continued use of retention-oriented practices such as long-term job security and corporate welfare, while Wang (2004) finds that employees at state-owned enterprises (SOEs) have higher levels of continuance commitment than those at foreign-owned enterprises. Chen and Francesco (2003) find that employee position has a significant effect on commitment, while Chen and Chen (2004) note that employee loyalty is more likely to be based on gratitude for individualised support from a supervisor than any perceived personal role obligations they may have. On the other hand, Snell (1999) points out that personal guanxi might lead to corruption. A similar view is shared by Ramasamy et al. (2006) who argue that personal guanxi can sometimes reflect the dark side of continual favour exchange. Park and Luo (2001) emphasise that in the Chinese business environment with its segmented factor markets and ambiguous property rights, guanxi, particularly personal guanxi, impedes the efficient allocation of economic resources, thereby resulting in less respect to organisational commitment. Thus, we expect a positive relationship between organisational guanxi in work environment and job commitment, but an unfavourable relationship between an employee's personal guanxi and job commitment.

$\mathrm{H} 2$ : There is a positive relationship between organisational guanxi and employee job commitment, and a negative relationship between personal guanxi and employee job commitment.

When studying organisational practices in China researchers are advised to pay attention to the five generally accepted primary types of organisations: (1) statecontrolled companies (including SOEs and collective ownership enterprises), (2) government organisations, (3) domestic private companies, (4) foreigncontrolled companies, and (5) joint ventures between Chinese and foreign multinationals. Murray and $\mathrm{Fu}$ (2016) study the different roles of guanxi in distribution channel management between foreign and domestic Chinese firms. 
They find that domestic firms emphasise preserving people, but foreign firms focus on standardising the process. In addition, Ralston, Kai-Cheng, Wang, and Terpstra (1996) caution that it is important to recognise regional difference in the Chinese economy while Su and Huang (1992), and Loscocco and Bose (1998) emphasise the significance of socio-demographic factors on job satisfaction. Thus, it can be hypothesise that:

H3: The relationship between guanxi and managerial practice (job satisfaction and job commitment) differs across gender, geography, and organisational type.

\section{METHODOLOGY}

\section{Survey Design and Collection}

A self-report questionnaire (see the Appendix) is designed to collect individual managers' perceptions of organisational and personal guanxi, job satisfaction, and organisational commitment. The conceptual framework for the guanxi items is based on theories of social exchange, leader-member exchange, Chinese trust principles of reciprocity and face. The concepts are operationalised by measuring social exchange acts before joining the company, social exchange acts with peers and supervisors at work, and deference to supervisors including social exchanges outside work and non-work related favours. It is captured using a ten 5-point Likert-type items ranging from "strongly disagree" to "strongly agree."

Research on job satisfaction suggests important contributory factors including socio-demographic variables such as age, gender, and education, as well as personality traits and work situational influences such as job characteristics and work relationships. Job satisfaction is also captured using items drawn from both previous Chinese and Western studies (Siu, Spector, Cooper, \& Lu, 2005). In China, studies suggest that job satisfaction is positively correlated with being male (Su \& Huang, 1992; Loscocco \& Bose, 1998), being older, being married, having employee involvement (Scott, Bishop, \& Chen, 2003), having a higher income (Nielsen \& Smyth, 2008), and having good environmental conditions such as adequate ventilation, illumination, workable space, etc. (Donald \& Siu, 2001). Therefore, we use multi-item indicators of satisfaction that include both facet-specific and global measures. Using these measures we are able to capture both intrinsic and extrinsic dimensions of the job as well as a validation question that assumes employees are able to balance disparate characteristics of their jobs to reach an overall assessment of job satisfaction. 
Organisational commitment is captured using items drawn from previous Chinese and Western studies: Chen and Francesco (2003); Wang (2004); Gamble and Huang (2008); Fu, Deshpande, and Zhao (2011). Questions were designed to capture affective, normative, and continuance commitment (Mowday et al., 1982; Meyer \& Allen, 1997), while being sensitive to Chinese context.

To collect the data, we use an online survey distributed by a Chinese survey company called Sojump. ${ }^{1}$ The survey is distributed to mid-level managers in four Chinese cities: Beijing, Shanghai, Guangzhou, and Shenzhen. These cities are chosen because of their economic diversity, firm accessibility, and geographic dispersion. Merrilees and Miller (1999) used a similar approach to empirically test the role of product and relationship drivers from a sample of 118 saleswomen in the cities of Shanghai, Guangzhou, Tianjin, and Dalian. The survey contains 42 questions and is divided into three sections: work environment, company, and demographic information. Response choices are unified to a 5-point Likert scale. The instrument is created in English, translated into Chinese, and back-translated into English to ensure accuracy.

\section{Review of Survey Responses}

In total, we receive 502 valid responses to our questionnaire. Descriptive statistics in Table 1 indicates that our survey covers a cross section of mid-level managers in China's business environment with $40.64 \%$ of subjects coming from Shanghai, $28.29 \%$ from Beijing, 18.92\% from Guangzhou, and 12.15\% from Shenzhen. The sample reasonably splits in terms of gender, with $52.19 \%$ male and $47.81 \%$ female. ${ }^{2}$ The average age is 32.91 years while $71.51 \%$ possess a bachelor degree, $15.54 \%$ a graduate degree, and $10.56 \%$ an associate degree. The importance of education in Chinese business has been documented by Fleisher, $\mathrm{Hu}$, and $\mathrm{Li}$ (2011), who find that for a broad sample of workers an additional year of education can increase marginal productivity by $18.3 \%$ to $24.5 \%$. Mayer and Puller (2008) find that having a college education exerts significant influence on building social networks at work.

More than $40 \%$ of subjects work in government-related organisations $(20.62 \%$ in state-controlled enterprises and $19.52 \%$ in the government itself) as well as $39.04 \%$ in the private sector. Joint ventures account for $10.56 \%$ of respondents and foreign-controlled companies a further $8.96 \%$. In terms of sectors, $22.49 \%$ of subjects work in information technology, $22.29 \%$ in finance-related industries, $21.47 \%$ for the public sector, and $9.2 \%$ in manufacturing. We also find that about $87 \%$ of firms in our sample have a history of more than 10 years, and most of them are large- or mid-size firms based on the number of hired employees (more than 
Table 1

Survey subjects by different characteristics

\begin{tabular}{|c|c|c|c|c|c|}
\hline \multirow{2}{*}{$\begin{array}{l}\text { Characteristics } \\
\text { City }\end{array}$} & \multicolumn{5}{|c|}{ Distribution } \\
\hline & Beijing & Shanghai & Guangzhou & Shenzhen & \\
\hline & $28.29 \%$ & $40.64 \%$ & $18.92 \%$ & $12.15 \%$ & \\
\hline \multirow[t]{2}{*}{ Gender } & Male & Female & & & \\
\hline & $52.19 \%$ & $47.81 \%$ & & & \\
\hline \multirow[t]{2}{*}{ Age (year) } & $<20$ & $20-30$ & $31-40$ & $41-50$ & $>50$ \\
\hline & $0.40 \%$ & $32.47 \%$ & $53.19 \%$ & $11.95 \%$ & $1.99 \%$ \\
\hline \multirow[t]{2}{*}{ Education } & High school & Associate & Bachelor & Graduate & \\
\hline & $2.39 \%$ & $10.56 \%$ & $71.51 \%$ & $15.54 \%$ & \\
\hline \multirow[t]{2}{*}{ Firm type } & $\begin{array}{c}\text { State } \\
\text { controlled }\end{array}$ & $\begin{array}{c}\text { Domestic } \\
\text { private }\end{array}$ & $\begin{array}{c}\text { Foreign } \\
\text { controlled }\end{array}$ & Joint ventures & Government \\
\hline & $20.62 \%$ & $39.04 \%$ & $8.96 \%$ & $10.56 \%$ & $19.52 \%$ \\
\hline \multirow[t]{4}{*}{ Industry sector } & Manufacture & Construction & Retail & Trans. and logi. & Hotel \& rest. \\
\hline & $9.20 \%$ & $5.93 \%$ & $4.91 \%$ & $4.29 \%$ & $3.48 \%$ \\
\hline & Real estate & Busi. (fina.) & IT & Public sector & \\
\hline & $5.93 \%$ & $22.29 \%$ & $22.49 \%$ & $21.47 \%$ & \\
\hline \multirow[t]{2}{*}{ Firm age (year) } & $<5$ & $5-10$ & $11-20$ & $21-40$ & $>40$ \\
\hline & $2.59 \%$ & $9.96 \%$ & $41.43 \%$ & $34.26 \%$ & $11.75 \%$ \\
\hline \multirow[t]{2}{*}{ Number of employees } & $1-100$ & $101-500$ & $501-1000$ & $1001-10,000$ & $>10,000$ \\
\hline & $14.54 \%$ & $30.28 \%$ & $27.89 \%$ & $23.51 \%$ & $3.78 \%$ \\
\hline \multirow[t]{2}{*}{ Previous jobs } & 0 & 1 & 2 & 3 & 4 or above \\
\hline & $15.14 \%$ & $34.86 \%$ & $32.27 \%$ & $14.94 \%$ & $2.79 \%$ \\
\hline \multirow[t]{2}{*}{ Length of service (year) } & $<1$ & $1-2$ & 3 & 4 & $>5$ \\
\hline & $2.79 \%$ & $11.75 \%$ & $17.13 \%$ & $16.73 \%$ & $51.59 \%$ \\
\hline \multirow[t]{2}{*}{ Monthly salary (USD) } & $161-806$ & $807-1,613$ & $1,614-3,226$ & $>3,226$ & \\
\hline & $12.75 \%$ & $46.81 \%$ & $33.86 \%$ & $6.57 \%$ & \\
\hline
\end{tabular}

Note: We receive 502 valid responses to our questionnaire. Due to rounding issue, the total percentages of each row may be slightly different from 100. In "Firm type" row, we do not report the proportion of "Other type" given that there are only five (less than $1 \%$ ) survey subjects choose this choice.

100 employees). Additionally, the majority of subjects have working experience for other organisations, with $17.73 \%$ having worked for three or more previous employers and $32.27 \%$ for two previous employers. More than half the subjects have spent more than five years with their current employers, and another $35 \%$ between three and five years. The employee compensation shows an expected range, namely about $80 \%$ subjects are paid with monthly salary from USD807 
to USD3,226. ${ }^{3}$ Given a time-consuming process of relationship building at work, strong representation of those survey subjects with long job tenure at large organisations increases the probability of detecting guanxi. In addition, most firms in our sample are mature organisations, so it is free of the bias of young enterprise as the operation in a young business may heavily rely on personal leadership or contingency. To summarise, these features of our sample strengthen the generalisability of our findings and therefore offer more meaningful conclusions.

\section{Survey analysis}

To test for internal consistency of our survey design, we first utilise the Cronbach's alpha test. Alpha values of job satisfaction variables and commitment variables are all around 0.89, greater than an acceptable level (0.6) for reliability (Kline, 2000). Therefore, our proxies for job satisfaction and commitment can serve as valid measures of the variables. Regarding guanxi, the alpha values range from 0.61 to 0.75 . As an additional assessment of proxy variation, we apply the KaiserMeyer-Olkin (KMO) test which measures the proportion of variance that can be caused by underlying factors. Since both the individual and overall KMO statistics are greater than 0.5 , we are confident in the reliability of the survey design. In conclusion, the variables of job satisfaction, commitment, and guanxi allow us to capture primary variation on how they interact with each other.

To get a basic sense of the relationship between guanxi and managerial practice, we report the Pearson correlation coefficients between guanxi and some selected variables of job satisfaction and commitment. ${ }^{4}$ The coefficients in Table 2 demonstrate some interesting findings. For example, we use $\mathrm{x} 1$ to measure the frequency of social activities between an employee and a superior, $\mathrm{x} 2$ to measure the extent to which a superior asks for an outside-of-work favour from an employee, and $\mathrm{x} 3$ to measure the extent to which an employee asks for an outside-of-work favour from a superior. These three are designed to capture the depth of the personal guanxi relationship after an employee is hired. In contrast, the variables $x 4, x 5$, and $x 6$ are primarily employed to gauge pre-employment personal guanxi. Interestingly, we find some negative and significant coefficients, suggesting that a pre-employment relationship leads to a low level of job satisfaction and commitment. Moreover, the variables x7, x8, x9, and $\mathrm{x} 10$ are found to be remarkably positive with the variables of job satisfaction and commitment. Recognising that variable $\mathrm{x} 7$ is a proxy for collaboration in the workplace and $\mathrm{x} 8$, $\mathrm{x} 9$, and $\mathrm{x} 10$ are proxies for the degree of organisational harmony, this correlation reveals a possibly positive association between organisational guanxi and job satisfaction or commitment. 


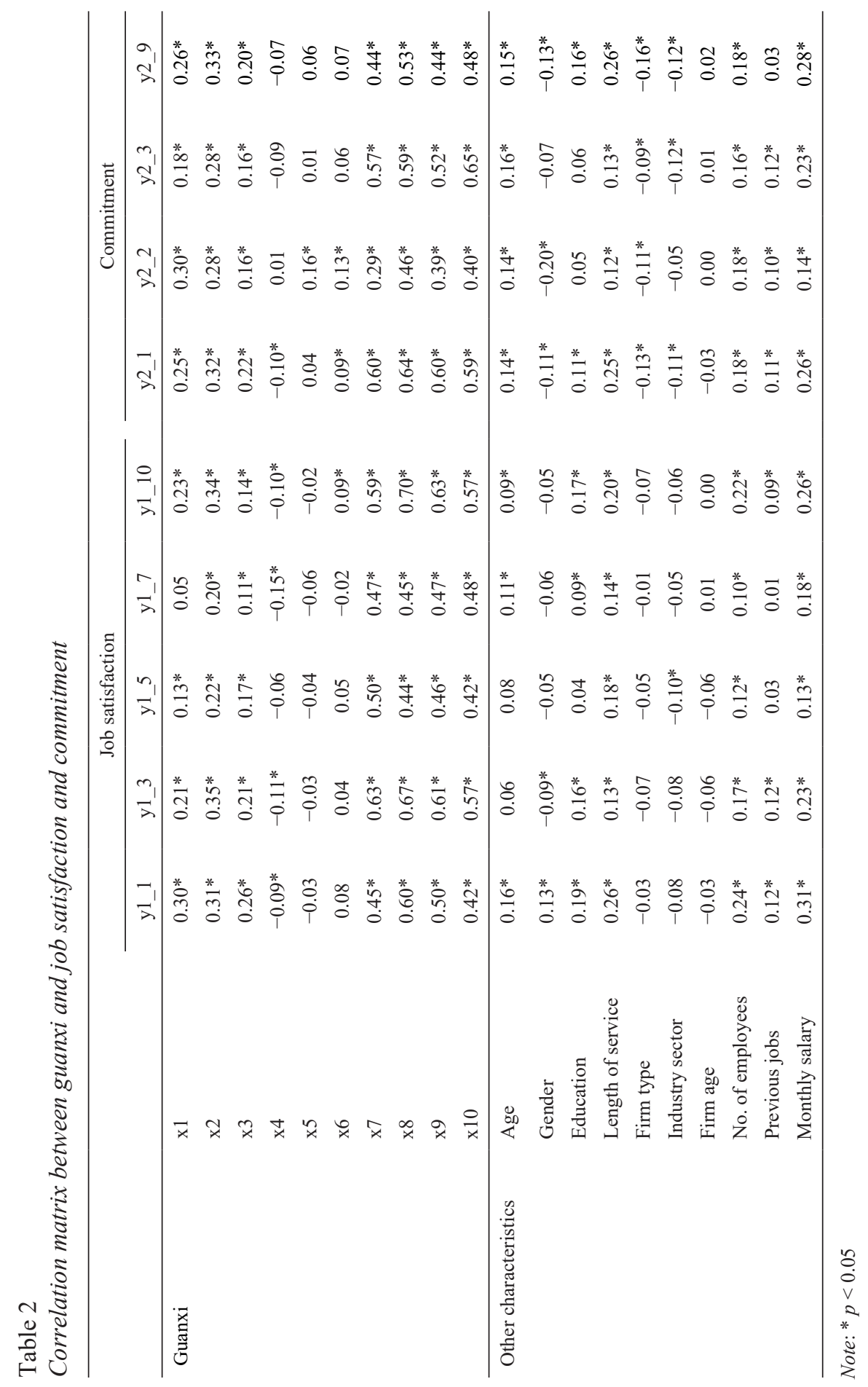


Additionally, the correlation coefficients between guanxi and other characteristics of responses are also investigated, including employee age, gender, education background, and etc. These results show important implications of guanxi in Chinese business and society. Firstly, there is a positive correlation between guanxi and employee age, length of service, and employee education. These findings imply that workplace guanxi increases with time. Secondly, we find that compensation (monthly salary) has a relatively strong correlation with the proxies of guanxi. Such evidence suggests that guanxi connections in organisations can be substantially affected by financial incentives. This is in keeping with Nielsen and Smyth's (2008) conclusion that the primary incentives employees considered when choosing a job were stability, high income, and professional development. This is echoed by Chiu, Luk, and Tang (2001) who find that money is a significant component of commitment, and has an important influence on attracting job seekers. This is noteworthy since a modernising Chinese economy continues to introduce a growing number of market-oriented or performancebased components such as position wages, skill wages, subsidies, bonuses, and profit sharing (Ding, Akhtar, \& Ge, 2006).

\section{Empirical Tests and Explanations}

\section{Principal component analysis (PCA)}

Given the fact that multiple questions are used in the survey to detect perceptions of guanxi, job satisfaction, and commitment, we apply PCA to compress the information contained in the multivariate data into low-dimensional data that describes perception and behaviours of the subjects in our sample. As PCA is essentially a variance of maximising process, the results discussed in this section are based on standardised data.

In two panels of Table 3, we report the results of PCA analysis and correlation between the new composited variable (e.g., principal components) and initial variables obtained from the survey. On Panel A, based on reported Eigenvalue (the cut-off level is 1), we find that the category of guanxi (X) has three primary components (GUANXI1, GUANXI2, and GUANXI3 hereinafter). These three components account for $64 \%$ of the cumulative explanation of the guanxi characteristics captured by our survey data. An analysis of Eigenvectors (Panel B) which lists the correlation between each of these three primary components and our initial 10 proxies (survey questions) of guanxi, further points out that GUANXI1 is highly correlated with $\mathrm{x} 7, \mathrm{x} 8, \mathrm{x} 9$, and $\mathrm{x} 10$ which measure work collaboration, i.e., organisational guanxi. For example, GUANXI1 has a correlation coefficient of 0.44 with $\mathrm{x} 9$ and 0.42 with $\mathrm{x} 7$. In contrast, GUANXI2 has more than 0.53 
correlation with $\mathrm{x} 4, \mathrm{x} 5$, and $\mathrm{x} 6$ which measure pre-employment personal guanxi. Finally, we see a considerable correlation between GUANXI 3 and $\mathrm{x} 1, \mathrm{x} 2$, and $\mathrm{x} 3$ which measure the post-working personal relationship between employers and employees. These results confirm that our 10 proxies successfully gauge the three dimensions of guanxi. By the same token, we find that the category of job satisfaction (Y1) has only one primary component (JOS) and the category of commitment (Y2) has two primary components (COM1 and COM2).

\section{Regression analysis}

After extracting the primary components of guanxi, job satisfaction, and commitment, we run further regressions to detect the influence of guanxi on job satisfaction and commitment. The results of ordinary least squares (OLS) regression are shown in Table 4.

GUANXI1, GUANXI2, and GUANXI3 comprise three main independent variables in each regression with JOS, COM1, COM2 making up three respective dependent variables. To ensure our results are not biased, we apply two model specifications in regressions. The first model specification contains only three main independent variables, namely, GUANXI1, GUANXI2, and GUANXI3 (see Models 1, 3, and 5), and while the second model specification additionally includes more control variables (see Models 2, 4, and 6). Therefore, in Table 4 we report the results of six regressions based on the full sample.

Firstly we find a significantly positive relation between GUANXI1 (organisational guanxi) and JOS (job satisfaction) in both Model 1 and Model 2, and a significantly negative relation between GUANXI2 (pre-working personal guanxi) and JOS as well as between GUANXI3 (post-working personal guanxi) and JOS. These suggest that organisational guanxi has a positive impact on job satisfaction but both post-working personal guanxi and pre-working personal guanxi have a negative influence on job satisfaction. Therefore, our first hypothesis is supported. Xian, Atkinson, and Meng-Lewis (2017) propose a mechanism of organisational guanxi that improves employees' positive perceptions of human resource practice. When employees who gain a favourable reciprocal relationship with peers, they will be likely to perceive positive aspects of human resource practice, which in turn will inform positive perceptions as to how they are treated in workplace. Zhai, Lindorff, and Cooper (2013) demonstrate that supervisor-subordinate guanxi developed during the business collaboration has a positive relationship with job satisfaction due to dispositional antecedents and mediating role of guanxi, while personal guanxi among co-worker does not show significant impact on job satisfaction. Our finding generally confirms their argument and indicates different roles of organisational guanxi and personal guanxi. 


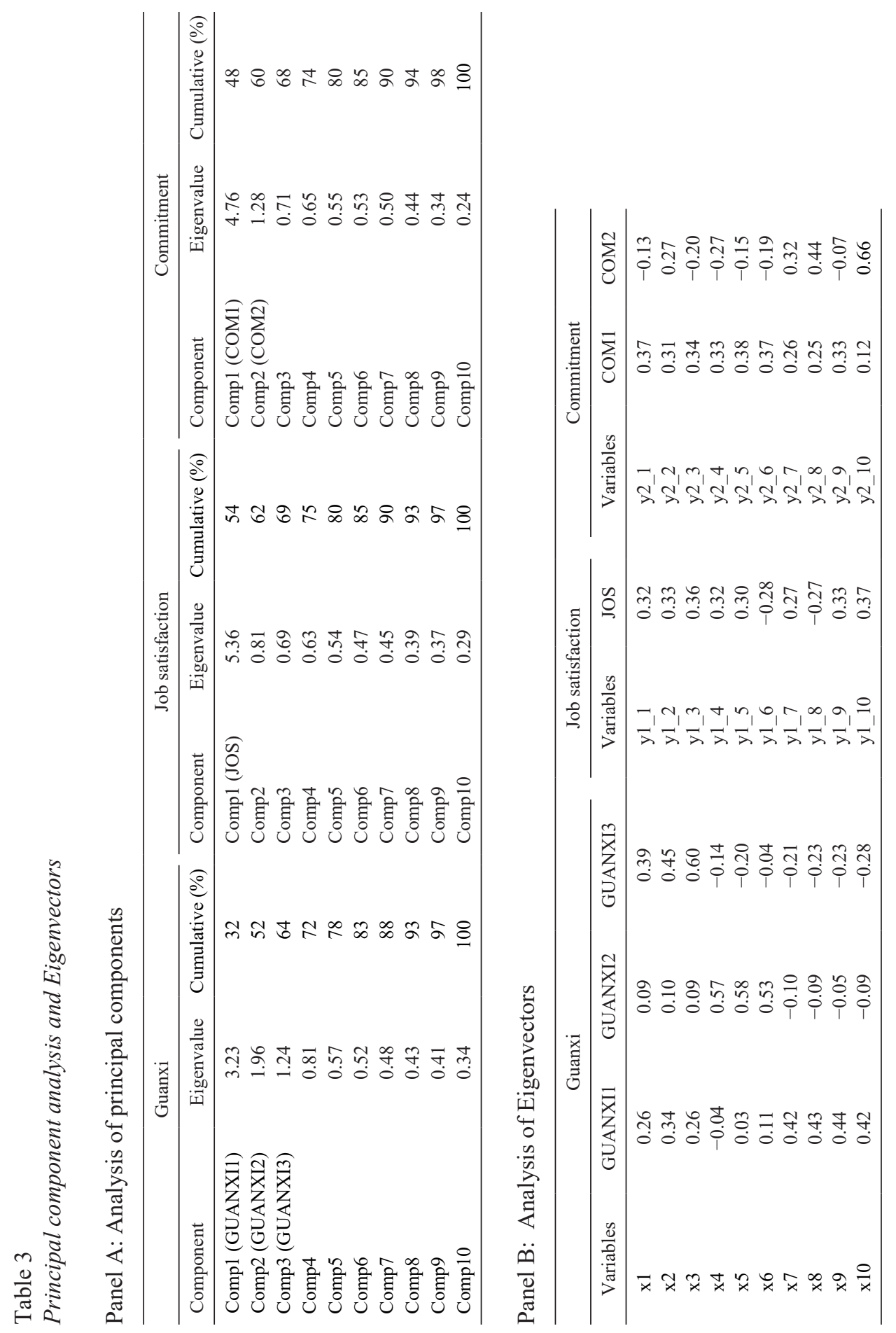




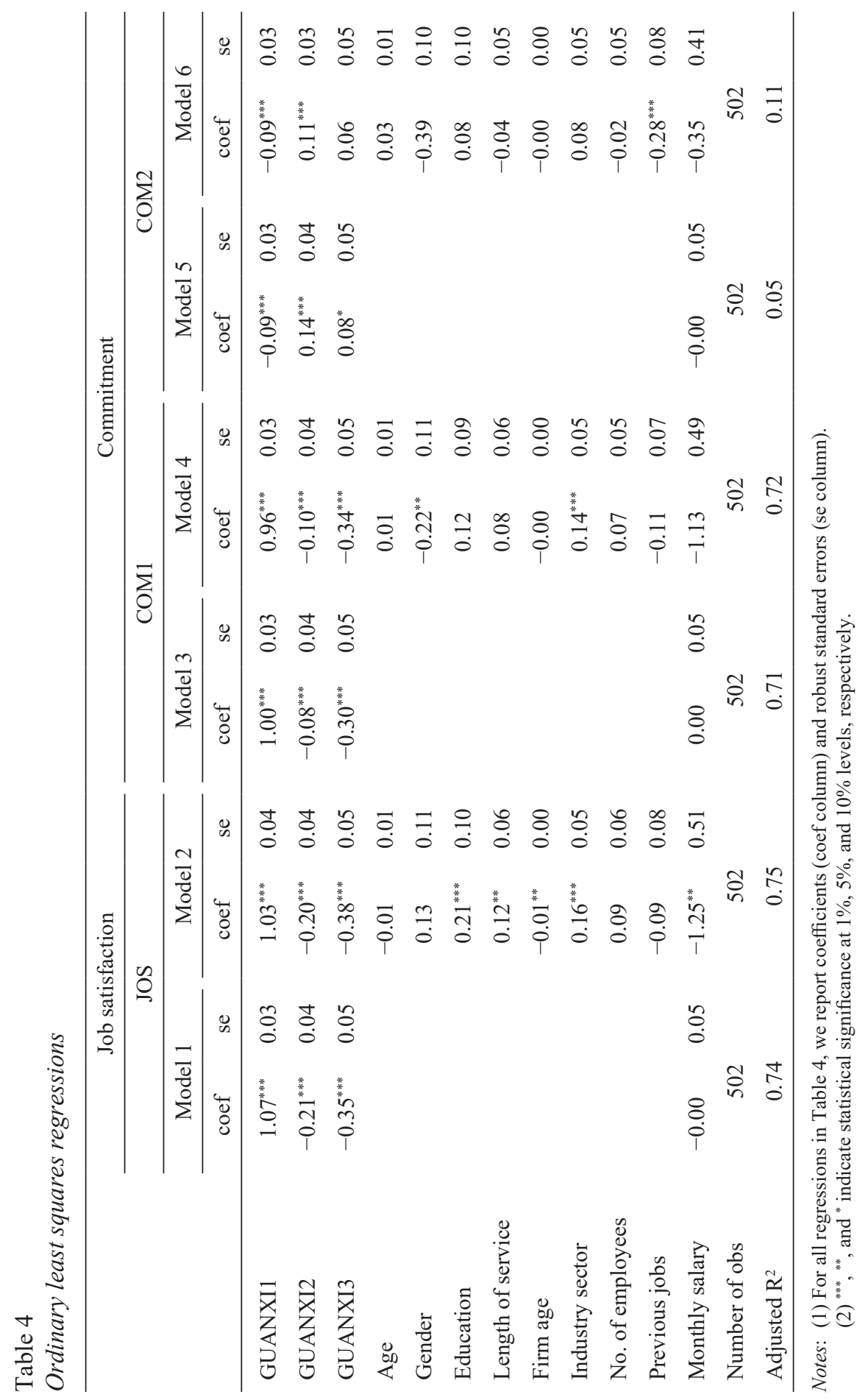


Secondly, Model 3 and Model 4 in Table 4 show the regressions of guanxi on COM1 (affective commitment). Particularly GUANXI1 has a significant and positive impact on COM1 with a coefficient of 0.96 in Model 4, which are consistent with our predication that more organisational guanxi leads to higher job commitment. This result is also in line of the research from Chen, Chang, and Lee (2015), who propose that guanxi assists the entrepreneurs in creative industry (e.g., architecture, filming, photography, publishing, performing arts, etc.) in acquiring information and resources, and more importantly, these benefits in turn in facilitating successful ventures to extend their guanxi networks. Creative industry is traditionally regarded as the occupation with high mobility. Nascent practitioners have to endure an unfavourable environment, whilst guanxi can be of important organisational factor helping the retention and hence influence their career success.

However, both GUANXI2 and GUANXI3 have a significant but negative impact on COM1 ( -0.10 and -0.34$)$, showing that greater personal guanxi has an opposite effect. For the results associated with COM2 (continuance or normative commitment), we also find different patterns. GUANXI1 has a significantly negative correlation with COM2 (-0.09 in Model 6), and GUANXI2 has a significantly positive correlation with COM2 (0.11 in Model 6), while no significant correlation is detected between GUANXI3 and COM2. These different patterns indicate that the impact of guanxi on continuance and normative commitment is different from that on affective commitment. Considering that personal guanxi is more likely to be involved with nepotism, it is not surprising to find a positive correlation between GUANXI2 (pre-working personal guanxi) and continuance commitment. Intuitively when the employment is procured through a family network or consanguinity, the entrenchment effect of position is likely to be strengthened. However, we find that such personal relationships have an adverse impact on affective commitment. Thus, our second hypothesis is partially supported. The findings imply that we need to distinguish the different components of guanxi as they influence managerial practice variously.

Finally, we test the models (with control variables) in subsamples that are grouped by geography, gender, and organisation type. ${ }^{5}$ While our main findings remain unchanged, we find some illuminating results and they also support our third hypothesis that the influence of guanxi components on job satisfaction and commitment may vary across geographic areas, gender, and industrial sectors. For example, in Panel A of Table 5, the pre-working personal guanxi (GUANXI2) and the post-working personal guanxi (GUANXI3) show a weaker impact on job satisfaction in Shenzhen than in the other three cities surveyed. This may be explained by the history of Shenzhen, which is a relatively new city populated 
The impact of guanxi on managerial practice

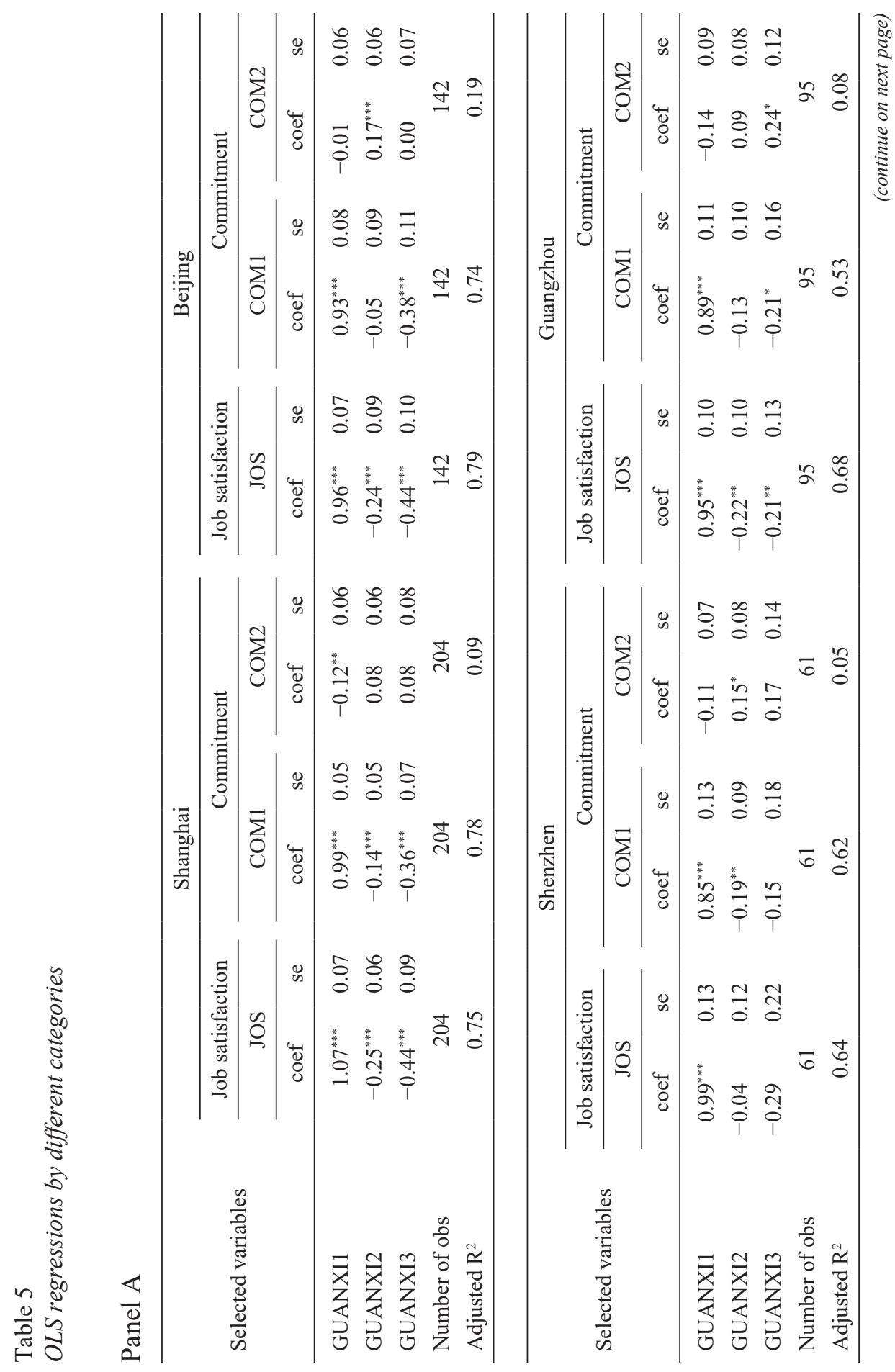


Jeffrey (Jun) Chen and Patrick F. O'Leary

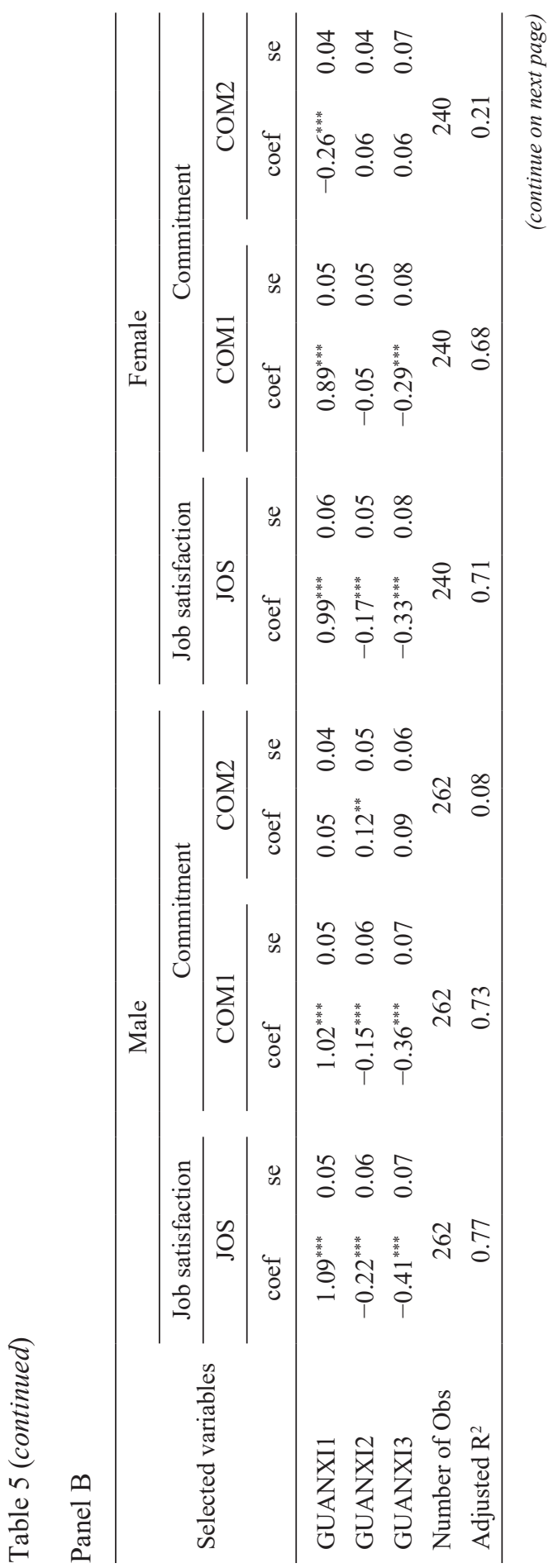




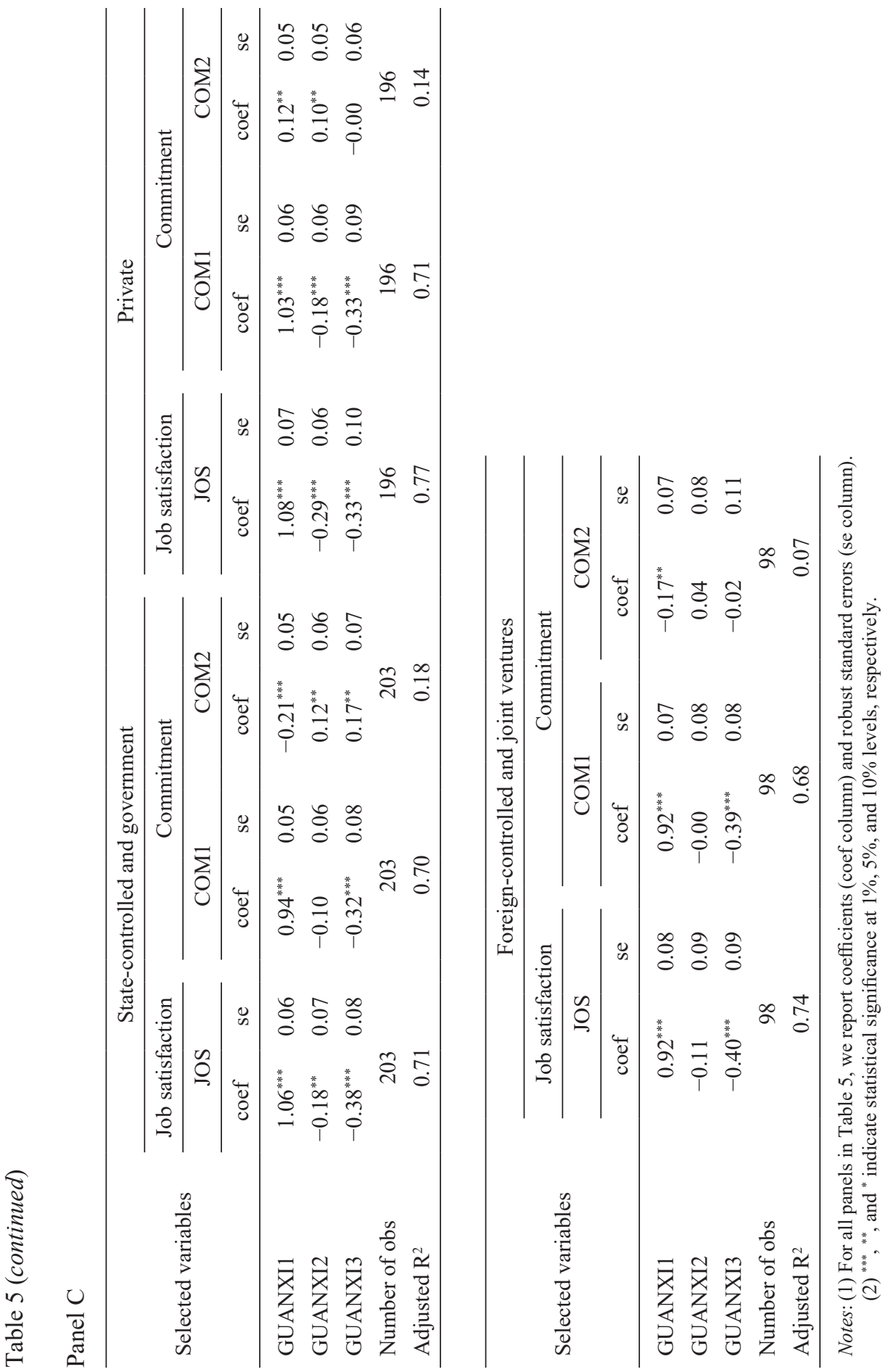


by the immigrants and developed with the business notion of market-orientation and liberalisation. Consistently, Opper, Nee, and Holm (2017) argue that guanxi may be strategically used in transactions with government authorities, such as access to bank loans, technology grants, public contracts, land permits, and export licenses. Their results suggest that the necessaries of guanxi activities will be weaker for business with more free-market orientation than for business with more government-planned orientation.

Scott, Harrison, Hussain, and Millman (2014) report that although guanxi networks also help female managers led ventures in China, guanxi connection is less important for them than for their male colleagues due to the work-family conflict. They further point out that the quality, rather than the quantity, of business contacts and mentors generated from guanxi is regarded as more important by female managers. In this research, we observe the consistent results from Panel $\mathrm{B}$ that the impact of pre-working personal guanxi (GUANXI2) on commitment is more pronounced to male managers than female managers. GUANXI2 has a significantly positive coefficient (0.12) on COM2 for the male group, but an insignificant coefficient (0.06) for the female group. The results show that preworking personal guanxi has a greater impact on the continuance commitment of male employees than their female counterparts.

In terms of organisation type, we separate the sample into three groups (statecontrolled and government organisations, domestic private firms, and foreigncontrolled and joint ventures). Murray and Fu (2016) report that most domestic Chinese firms treat recruiting process as an important channel to acquire existing guanxi into their organisations. In contrast, foreign firms focus on developing new guanxi via company-sponsored programmes. Such distinction may predict diverse outcome. Significantly, in Panel $\mathrm{C}$ we find that pre-working guanxi (GUANXI2) has a weaker impact (-0.11) on the job satisfaction of managers in foreign-controlled firms and joint ventures. Lastly, the impact of GUANXI3 (post-working personal guanxi) on COM2 is found to be significant only for statecontrolled firms and government. Therefore, our third hypothesis is supported by the empirical results. Taken together, our overall empirical findings are summarised as follows:

1. Overall, guanxi is significantly associated with managerial commitment and job satisfaction in Chinese business.

2. Organisational guanxi is confirmed to enhance job satisfaction, promotes affective commitment but has a detrimental impact on continuance and normative commitment. 
3. Personal guanxi leads to more continuance and normative commitment but reduces job satisfaction and affective commitment.

4. The influence of personal guanxi is the weakest in the area where the business is more market-oriented and liberalised.

5. The impact of personal guanxi on commitment is more pronounced to male managers than female managers, but there is no significant difference on job satisfaction between male managers and female managers.

6. The job commitment of managers in foreign firms and joint ventures are less affected by personal guanxi than the job commitment of managers in state-controlled firms and government.

\section{CONCLUSION AND IMPLICATIONS}

This paper finds that guanxi has significant impacts on job satisfaction and organisational commitment. More importantly, the structural influences from different dimensions of guanxi are observed. While this research provides strong empirical evidence that guanxi continues to play a significant role in Chinese workplace practices and outcomes, our study finds that its impact and practice are informed by industry and organisational type. The findings of a situational source of organisational guanxi and job satisfaction suggest companies can indeed impact employee attitudes and emotional commitment. On the other hand, the dispositional source of personal guanxi and normative commitment imply that employees' sense of obligation to the organisation cannot be easily shaped by organisational inputs.

This study incorporated complex Chinese norms of trust with Western social and leader-member exchange theories, suggesting a hybridisation effect. It supports social identity theory in predicting the relationships between guanxi and affective commitment as organisational guanxi facilitates the building of group identity and a sense of group inclusion. Practical implications show high correlations workplace guanxi, job satisfaction, and affective commitment demonstrating the critical nature of the supervisor-subordinate relationship in Chinese organisations.

As organisational guanxi depends on social exchange and reciprocity, foreign companies need to recognise its role in the workplace and train their employees in the importance of context and high-touch in workplace interactions. Further, they might consider leaving their managers and supervisors in place for enough time to develop meaningful relationships with peers and subordinates. Supervisors should 
be cognizant of the importance of bidirectional communication with subordinates and be able to deal with ambiguity and the possibility of paradox in workplace interaction. In contrast with the Western orientation where goodwill is assumed, they must understand that in China it has to be earned.

\section{LIMITATION AND FUTURE RESEARCH}

The current research has a number of limitations that should be addressed in future research. Firstly, this is an exploratory study and the findings need further testing. Secondly, since this is a cross-sectional study using the self-report survey method to collect data, it is difficult to make definite causal claims on the relationship between workplace guanxi, job satisfaction, and organisational commitment. Nevertheless, despite differences in the demographic, geographical, work environment, and sector characteristics of subjects, some broad similarity of attitudes and practices emerged. This consistency suggests that our results may be applicable to a broader population and we invite future researches to investigate.

This study assumed a causal relationship between guanxi and job satisfaction and between guanxi and organisational commitment, but as Cheung et al. (2009) note, it is also possible that job satisfaction could be the mediating factor between affectivity and guanxi. This proposition should be explored further. In addition, future researchers might explore the mediating role of guanxi on Mintzberg's (1989) 10 managerial roles.

Observers of China have suggested that the practice and importance of guanxi is likely to change as the socio-economic environment develops. A longitudinal study to investigate this claim would be valuable. Finally, this study was conducted in the Chinese cities of Beijing, Shanghai, Guangzhou, and Shenzhen. These are all extremely modern and globalised cities. Future research might conduct similar research in less developed regions and less globalised cities.

Despite these limitations, this study provides a nuanced understanding of organisational guanxi, and the nuances of doing business in contemporary China. It is important to further this understanding through more empirical research. 


\section{NOTES}

1. Sojump's website: https://www.wjx.cn/

2. According to the report from CATALYST, women account for $48.5 \%$ of China's total population in 2011 and $45.3 \%$ of total labour force

3. The amounts of US dollar shown in Table 1 are converted from Chinese currency with initial scales: $[1,000-5,000],[5,001-10,000],[10,001-20,000]$ and $[>20,000]$

4. To save space, we do not show all results for the variables of job satisfaction and commitment in Table 2. The complete correlation coefficients are available on request.

5. To save space, we only report the coefficients of selected variables (GUANXI1, GUANXI2, and GUANXI3) in Panel A through Panel $\mathrm{C}$ of Table 5. The tables with complete coefficients are available on request. 


\section{APPENDIX}

\begin{tabular}{|c|c|c|}
\hline Categories & Variables & Survey questions \\
\hline \multirow[t]{10}{*}{ Job satisfaction } & y1_1 & My salary is adequate given my training and experience. \\
\hline & y1_2 & My work is intellectually stimulating. \\
\hline & y1_3 & My boss treats me fairly and has my long-term interests at heart. \\
\hline & y1_4 & $\begin{array}{l}\text { If I were to start my career over again, I would choose a similar } \\
\text { path. }\end{array}$ \\
\hline & y1_5 & My work colleagues are an important source of personal support. \\
\hline & y1_6 & My work in this company has not met my expectations. \\
\hline & y1_7 & $\begin{array}{l}\text { My promotional prospects are based on my ability and } \\
\text { performance. }\end{array}$ \\
\hline & y1_8 & If possible I would leave this company. \\
\hline & y1_9 & I receive sufficient, ongoing, professional training. \\
\hline & y1_10 & Overall I am pleased with my work here. \\
\hline \multirow[t]{10}{*}{ Commitment } & y2_1 & Emotionally, I love my company so much. \\
\hline & y2_2 & I think it is unethical to quit my job and change to another one. \\
\hline & y2_3 & I think I should contribute all efforts to this company. \\
\hline & y2_4 & I've had several chances to attend short-term advanced studies. \\
\hline & y2_5 & I've had many chances to be promoted here. \\
\hline & y2_6 & The working environment here is beneficial to my career. \\
\hline & y2_7 & $\begin{array}{l}\text { My company pays for my house fund, pension fund, and child } \\
\text { care. }\end{array}$ \\
\hline & y2_8 & I cannot leave here even if I wanted to. \\
\hline & y2_9 & $\begin{array}{l}\text { I have devoted my life to this company, it will be a huge loss for } \\
\text { me if I leave here. }\end{array}$ \\
\hline & y2_10 & It is not easy for me to find another good job. \\
\hline \multirow[t]{10}{*}{ Guanxi } & $\mathrm{x} 1$ & How often do you go out for social activities with your superior? \\
\hline & $\mathrm{x} 2$ & $\begin{array}{l}\text { Has your superior ever asked you for a favour which is not } \\
\text { relevant to your job? }\end{array}$ \\
\hline & $\mathrm{x} 3$ & $\begin{array}{l}\text { Have you ever received favours from your superior which are not } \\
\text { relevant to your job? }\end{array}$ \\
\hline & $\mathrm{x} 4$ & $\begin{array}{l}\text { How did you know about this company before you considered } \\
\text { joining it? }\end{array}$ \\
\hline & $\mathrm{x} 5$ & How did you get the interview opportunity? \\
\hline & x6 & Did you know any people in this company before you came here? \\
\hline & $\mathrm{x} 7$ & I have a good relationship with my boss. \\
\hline & $\mathrm{x} 8$ & This company has met my pre-entry expectations. \\
\hline & x9 & I have developed many important relationships in this company. \\
\hline & $\mathrm{x} 10$ & I feel an obligation to do my best and stay with this company. \\
\hline
\end{tabular}




\section{REFERENCES}

Allott, J., Gibb, J., \& Akoorie, M. (2017). Low propensity to trust and guanxi: A model of creation strategies in small businesses. Academy of Management Proceedings (vol. 2017, no. 1, pp. 40 pages). https://doi.org/10.5465/ambpp.2017.12030abstract

Bakker, A.B., \& Demerouti, E. (2007). The job demands-resources model: State of the art. Journal of Managerial Psychology, 22(3), 309-328. https://doi. org $/ 10.1108 / 02683940710733115$

Bedford, O. (2011). Guanxi-building in the workplace: A dynamic process model of working and backdoor guanxi. Journal of Business Ethics, 104(1), 149-158. https://doi.org/10.1007/s10551-011-0895-9

Blau, P. (1977). Inequality and heterogeneity: A primitive theory of social structure. New York: The Free Press.

Blois, K. (1999). Trust in business to business relationships: An evaluation of its status. Journal of Management Studies, 36(2), 197-215. https://doi.org/10.1111/14676486.00133

Chen, C.C., Chen, X.P., \& Huang, S. (2013). Guanxi and social network research: Review and future directions. Management and Organization Review, 9(1), 167-207. https://doi.org/10.1111/more.12010

Chen, M., Chang, Y., \& Lee, C. (2015). Creative entrepreneurs' guanxi networks and success: Information and resource. Journal of Business Research, 68(4), 900905. https://doi.org/10.1016/j.jbusres.2014.11.049

Chen, X.P., \& Chen, C.C. (2004). On the intricacies of the Chinese guanxi: A process model of guanxi development. Asia Pacific Journal of Management, 21(3), 305324. https://doi.org/10.1023/B:APJM.0000036465.19102.d5

Chen, Z.X., \& Francesco, A.M. (2003). The relationship between the three components of commitment and employee performance in China. Journal of Vocational Behavior, 62(3), 490-510. https://doi.org/10.1016/S0001-8791(02)00064-7

Cheung, M., Wu, W.-P., Chan, A., \& Wong, M. (2009). Supervisor and subordinate guanxi and employee work outcomes: The mediating role of job satisfaction. Journal of Business Ethics, 88(Supp.1), 77-89. https://doi.org/10.1007/s10551-008-9830-0

Chiu, R.K., Luk, V.W.M., \& Tang, T.L.P. (2001). Hong Kong and China: The cash mentality revisited. Compensation and Benefits Review, 33(3), 66-72. https://doi. org/10.1177/08863680122098324

Ding,D.,Akhtar,S.,\&Ge,G.L.(2006).Organizationaldifferencesinmanagerialcompensation and benefits in Chinese firms. International Journal of Human Resource Management, 17(4), 693-715. https://doi.org/10.1080/09585190600581675

Donald, I., \& Siu, O.L. (2001) Moderating the stress impact of environmental conditions: The effect of organizational commitment in Hong Kong and China. Journal of Environmental Psychology, 21(4), 353-368. https://doi.org/10.1006/ jevp.2001.0229

Fan, Y. (2002). Guanxi's consequences: Personal gains at social cost. Journal of Business Ethics, 38(4), 371-380. https://doi.org/10.1023/A:1016021706308

Fang T. (1999). Chinese business negotiating style. Thousand Oaks, CA: Sage Publications. 
Fleisher, B.M., Hu, Y., \& Li, H. (2011). Economic transition, higher education and worker productivity in China. Journal of Development Economics, 94(1), 86-94. https:// doi.org/10.1016/j.jdeveco.2010.01.001

Fu, W., Deshpande, S. P., \& Zhao, X. (2011). The impact of ethical behavior and facets of job satisfaction on organizational commitment of Chinese employees. Journal of Business Ethics, 104(4), 537-543. https://doi.org/10.1007/s10551-011-0928-4

Gamble, J., \& Huang, Q. (2008). Organizational commitment of Chinese employees in foreign invested firms. International Journal of Human Resource Management, 19(5), 896-916. https://doi.org/10.1080/09585190801993893

Gandz, J., \& Murray, V.V. (1980). The experience of workplace politics. Academy of Management Journal, 23(2), 237-251. https://doi.org/10.5465/255429

Gannon, M.J., \& Pillai, R. (2013). Understanding global cultures: Metaphorical journeys through 31 nations. Thousand Oaks, CA: Sage Publications.

Graen, G.B., \& Uhl-Bien, M. (1991). The transformation of professionals into selfmanaging and partially self-designing contributions: Toward a theory of leadermaking. Journal of Management Systems, 3(3), 33-48.

Han, Y., Peng, Z., \& Zhu, Y. (2012). Supervisor-subordinate guanxi and trust in supervisor: A qualitative inquiry in the People's Republic of China. Journal of Business Ethics, 108(3), 313-324. https://doi.org/10.1007/s10551-011-1092-6

Homans, G. (1961). Social behavior: Its elementary forms. New York: Harcourt Brace Jovanovich.

Kahn, W.A. (1990). Psychological conditions of personal engagement and disengagement at work. Academy of Management Journal, 33(4), 692-724. https://doi. org/10.5465/256287

Kline, P. (2000). The handbook of psychological testing (2nd ed.). London: Routledge.

Li, P.P. (2007a). Guanxi as the Chinese norm for personalized social capital: Toward an integrated duality framework of informal exchange. In H.W., Yeoung (Ed.), Handbook of research on Asian business, (pp. 62-83). Cheltenham: Edward Elgar.

Li, P.P. (2007b). Social tie, social capital, and social behavior: Toward an integrative model of informal exchange. Asia-Pacific Journal of Business Management, 24(2), 227-246. https://doi.org/10.1007/s10490-006-9031-2

Lo, K. D. (2012). Chinese guanxi and Anglo-American networking: A comparative investigation of cross-cultural interpersonal business relationships. The Journal of International Management Studies, 7(2), 216-223.

Loscocco, K.A., \& Bose, C.E. (1998). Gender and job satisfaction in urban China: The early post-Mao period. Social Science Quarterly, 79(1), 91-109.

Mayer A., \& Puller, S.L. (2008). The old boy (and girl) network: Social network formation on university campuses. Journal of Public Economics, 92(1-2), 329-347. https:// doi.org/10.1016/j.jpubeco.2007.09.001

Merrilees, B., \& Miller, D. (1999). Direct selling in the West and East: The relative roles of product and relationship (guanxi) drivers. Journal of Business Research, 45(3), 267-273. https://doi.org/10.1016/S0148-2963(97)00238-5

Meyer, J.P., \& Allen, N.J. (1997). Commitment in the workplace: Theory, research, and application. Newbury Park, CA: Sage Publications. 
Mintzberg, H. (1989). Mintzberg on management: Inside our strange world of organizations. New York: Hungry Minds Inc.

Morgan, R.M., \& Hunt, S.D. (1994). The commitment-trust theory of relationship marketing. Journal of Marketing, 58(3), 20-38. https://doi.org/10.2307/1252308

Mowday, R.R., Porter, L.W., \& Steer, R.M. (1982). Employee-organization linkages: The psychology of commitment, absenteeism, and turnover. New York: Academic Press.

Murray, J.Y., \& Fu, F.Q. (2016). Strategic guanxi orientation: How to manage distribution channels in China? Journal of International Management, 22(1), 1-16. https://doi.org/10.1016/j.intman.2015.10.003

Nielsen, R., \& Smyth, R. (2008). Job satisfaction and response to incentives among China's urban workforce. The Journal of Socio-Economics, 37(5), 1921-1936. https://doi. org/10.1016/j.socec.2008.02.008

Opper, S., Nee, V., \& Holm, H.J. (2017). Risk aversion and guanxi activities: A behavioral analysis of CEOs in China. Academy of Management Journal, 60(4), 1504-1630. https://doi.org/10.5465/amj.2015.0355

Park S.H., \& Luo, Y. (2001). Guanxi and organizational dynamics: Organizational networking in Chinese firms. Strategic Management Journal, 22(5), 455-477. https://doi.org/10.1002/smj.167

Pun, K.F., Chin, K.S., \& Lau, H.(2000). A review of the Chinese cultural influences. International Journal of Management Review, 2(4), 325-338. https://doi. org/10.1111/1468-2370.00045

Ralston, D.A., Kai-Cheng, Y., Wang. X., \& Terpstra, R.H. (1996). The cosmopolitan Chinese manager: Findings of a study on managerial values across the six regions of China. Journal of International Management, 2(2), 79-109.

Ramasamy, B., Goh, K.W., \& Yeung, M.C.H. (2006). Is guanxi (relationship) a bridge to knowledge transfer? Journal of Business Research, 59(1), 130-139. https://doi. org/10.1016/j.jbusres.2005.04.001

Schwartz, S.H. (1999). A theory of cultural values and some implications for work. Applied Psychology: An International Review, 48(1), 23-47. https://doi. org/10.1111/j.1464-0597.1999.tb00047.x

Scott, D., Bishop, J.W., \& Chen, X. (2003). An examination of the relationship of employee involvement with job satisfaction, employee cooperation, and intention to quit in U.S. invested enterprise in China. The International Journal of Organizational Analysis, 11(1), 3-19. https://doi.org/10.1108/eb028960

Scott, M.J.T., Harrison, R., Hussain, J., \& Millman, C. (2014). The role of guanxi networks in the performance of women-led firms in China. International Journal of Gender and Entrepreneurship, 6(1), 68-82. https://doi.org/10.1108/IJGE-03-2013-0014

Siu, O.L., Spector, P.E., Cooper, C.L., \& Lu, C.Q. (2005). Work stress, self-efficacy, Chinese work values, work well-being in Hong Kong and Beijing. International Journal of Stress Management, 12(3), 274-288. https://doi.org/10.1037/10725245.12.3.274

Snell, R. (1999). Obedience to authority and ethical dilemmas in Hong Kong companies. Business Ethics Quarterly, 9(3), 507-526. https://doi.org/10.2307/3857514 
Staw, B.M., \& Cohen-Charash, Y. (2005). The dispositional approach to job satisfaction: More than a mirage, but not yet an oasis. Journal of Organizational Behavior, 26(1), 59-78. https://doi.org/10.1002/job.299

Su, S.L., \& Huang, K.L. (1992). Secondary school teachers' attitudes towards teachers' union participation and strikes. Education and Psychology Research, 15, 173214.

Takeuchi, N., Wakabayashi, M., \& Chen, Z. (2003). The strategic HRM configuration for competitive advantage: Evidence from Japanese firms in China and Taiwan. Asia Pacific Journal of Management, 20(4), 447-480. https://doi.org/ 10.1023/A:1026386925473

Tsui, A., Farh, J., \& Xin, K. (2000). Guanxi in the Chinese context. In J. Li, A. Tsui, \& E. Weldon (Eds.), Management and organizations in the Chinese context (pp. 224-242). New York: Macmillan. https://doi.org/10.1057/9780230511590_9

Wang, Y. (2004). Observations on the organizational commitment of Chinese employees: Comparative studies of state-owned enterprises and foreign-invested enterprises. The International Journal of Human Resource Management, 15(4-5), 649-669. https://doi.org/10.1080/0958519042000192889

Warner, M. (2010). In search of confucian HRM: Theory and practice in Great China and beyond. International Journal of Human Resource Management, 21(12), 20532078. https://doi.org/10.1080/09585192.2010.509616

Watt, L. (1999). Managing in the PRC. Better Management, 35(December), 24-28.

Wei, L., Liu, J., Chen, Y., \& Wu, L. (2010). Political skill, supervisor-subordinate guanxi and career prospects in Chinese firms. Journal of Management Studies, 47(3), 437-454. https://doi.org/10.1111/j.1467-6486.2009.00871.x

Wong, Y.T., Ngo, H., \& Wong, J.M. (2003). Antecedents and outcomes of employees' trust in Chinese joint ventures. Asia Pacific Journal of Management, 20(4), 481499. https://doi.org/10.1023/A:1026391009543

Xian, H., Atkinson, C., \& Meng-Lewis, Y. (2017). Guanxi and high performance work systems in China evidence from a state owned enterprise. The International Journal of Human Resource Management, 28, 1-19. https://doi.org/10.1080/09 585192.2017.1332670

Zhai, Q., Lindorff, M., \& Cooper, B. (2013). Workplace guanxi: Its dispositional antecedents and mediating role in the affectivity-job satisfaction relationship. Journal of Business Ethics, 117(3), 541-551. https://doi.org/10.1007/s10551012-1544-7

Zhang, Y., Long, L., Wu, T.Y., \& Huang, X. (2015). When is pay for performance related to employee creativity in the Chinese context? The role of guanxi HRM practice, trust in management, and intrinsic motivation. Journal of Organizational Behavior, 36(5), 698-719. https://doi.org/10.1002/job.2012 